\title{
EFFECTS OF GERMINATION CONDITIONS ON PEPTIDES ACCUMULATION IN SOYBEAN (GLYCINE MAX L. MERR.)
}

\author{
Y. Zou* and X. Hou \\ College of Life Science, Dalian Nationalities University, Liaohexi Road 18, 116600 Dalian. China
}

(Received: 13 October 2016; accepted: 15 December 2016)

\begin{abstract}
High levels of peptides can accumulate in tissues of legumes during germination. In this study, effects of germination conditions ( $\mathrm{pH}$, temperature, and time) on protease activity and peptides accumulation in soybean were investigated. The desirable level scope of parameters was used to further optimise germination conditions for peptides accumulation using response surface methodology. Results showed that protease activity and peptides yield were significantly influenced by $\mathrm{pH}$, temperature, and time $(\mathrm{P}<0.05)$. The optimal $\mathrm{pH}$, temperature, and time for protease activity were $5,25^{\circ} \mathrm{C}$, and 6 days, respectively. Meanwhile, the optimal $\mathrm{pH}$, temperature, and time for peptides content were $5,30^{\circ} \mathrm{C}$, and 5 days, respectively. Box-Behnken design indicated the following optimal germination conditions: $\mathrm{pH} 4.8$, temperature $29^{\circ} \mathrm{C}$, and time 5 days. Under these conditions, the highest peptides content $(14.46$ $\mathrm{mg} \mathrm{g}^{-1} \mathrm{FW}$ ) in germinated soybean was obtained. The present study indicates that germinated soybean can be a valuable component of peptides-enriched foods.
\end{abstract}

Keywords: soybeans, germination conditions, peptides, accumulation

Soybean (Glycine $\max$ L. Merr.) is a very old legume and mainly consumed in Asian countries (Liv et al., 2008). In the Orients, soybean has been used as food for more than 6000 years (Agarwal et al., 2013). In China, soybean is consumed as soy sauce, cooked beans, tofu, or soy milk. It is an inexpensive source of carbohydrates, dietary proteins, and fats. Other important chemical components are isoflavones and lignans, well-known for their beneficial effects on human health due to their antioxidant activity (SHAO et al., 2009). However, the nutritional value of soybean is limited by the presence of antinutritional components such as phytic acid, tannins, and trypsin inhibitors (Dis et al., 2012). It is important to search for a process that can degrade antinutritional components and further improve healthful function of soybean.

Nutritional and antinutritional components in legumes can be modified by sprouting. Compared with raw seeds, amounts of antinutrients sharply decrease, while contents of minerals including calcium, iron, and zinc gradually increase during legumes germination (KUMARI et al., 2015). Moreover, proteins are broken down and converted into a variety of peptides during germination. Peptides are better absorbed than single amino acids during gastrointestinal digestion and have a number of healthful functions such as antioxidation, antimicrobial properties, antihypertensive effect, antithrombotic and immunomodulatory activities (PrZybylski et al., 2016). These functions endow peptides-enriched germinated soybean with great development potential as a healthful food.

Response surface methodology (RSM) is an effective statistical technique and its main advantage is the reduced number of experimental trials required to evaluate multiple

\footnotetext{
* To whom correspondence should be addressed. Phone: +86411 87656215; e-mail: yuzou126@126.com
} 
parameters and their interactions (MunE MunE et al., 2014). It is less laborious and timeconsuming compared with other approaches. RSM is one of the most popular statistical techniques in the field of food science (Mune Mune et al., 2008; PeÑas et al., 2010). The germination conditions for accumulation of valuable compounds in some germinated cereals and legumes have been optimised using RSM with Box-Behnken design (BAI et al., 2008). It is considered that $\mathrm{pH}$ value of culture solution, germination temperature, and germination time are the main parameters that can influence peptides content (WEN et al., 2009; HüBNER \& ARENDT, 2010). However, there is little information available in the literature about the investigation of effects of germination conditions on peptides accumulation of soybean.

The objective of this study was to provide scientific information for the development of peptides-enriched germinated soybean. The effects of germination conditions $(\mathrm{pH}$, temperature, and time) on protease activity and peptides accumulation were investigated. RSM was employed to further optimise germination conditions in order to obtain the maximal peptides yield.

\section{Materials and methods}

\subsection{Materials and reagents}

Soybean seeds (JinYou, cultivated in the Northeast Region of China and harvested in 2015) of the same batch in Tonghua City (Jilin Province, China) were collected from local market and stored at $-20{ }^{\circ} \mathrm{C}$ until used. L-Glutathione and L-tyrosine were purchased from SigmaAldrich Chemical Co. (St. Louis, Mo, USA). All other reagents were obtained from Sinopharm Chemical Regent Co., Ltd. (Shanghai, China) and were of analytical grade.

\subsection{Seed germination}

Twenty grams of soybean seeds were surface sterilized by soaking in $10 \mathrm{ml} \mathrm{l}^{-1}$ sodium hypochlorite for $30 \mathrm{~min}$, then rinsed and steeped in distilled water for $6 \mathrm{~h}$ at $25^{\circ} \mathrm{C}$. Soaked seeds were then germinated on a filter paper in Petri dishes $(15 \mathrm{~cm}$ in diameter) filled with 20 $\mathrm{ml}$ of culture solution (citric acid-phosphate buffer, $\mathrm{pH} 4$ ) and grown in incubators at $25^{\circ} \mathrm{C}$ in darkness for 4 days. Seeds were supplied with culture solution at $12 \mathrm{~h}$ intervals until germination was complete. The germinated seeds were washed with distilled water and dried with a filter paper. The samples were then frozen in liquid nitrogen and stored in a refrigerator at $-20{ }^{\circ} \mathrm{C}$ for further experiments.

\subsection{Effects of germination conditions on protease activity and peptides accumulation}

In order to determine the proper scope of germination conditions for protease activity and peptides accumulation in soybean, different levels of parameters were performed as follows: various $\mathrm{pH}$ values of culture solution ranging from 3 to 7 , germination temperature ranging from 15 to $35{ }^{\circ} \mathrm{C}$, and germination time ranging from 2 to 6 days. The desirable level scope of parameters resulting in higher peptides yield was used to optimize germination conditions for peptides accumulation in soybean with RSM. 


\subsection{Optimisation of germination conditions for peptides accumulation}

The germination conditions including $\mathrm{pH}\left(X_{1}\right)$, temperature $\left(X_{2}\right)$, and time $\left(X_{3}\right)$, were chosen as independent variables in Box-Behnken experimental design. Based on the single-factor experiments, $X_{1}(4,5$, and 6$), X_{2}\left(25,30\right.$, and $\left.35^{\circ} \mathrm{C}\right)$, and $X_{3}(4,5$, and 6 days) were determined as critical levels with significant effect oneptides accumulation in germinated soybean (Table 1$)$.

Table 1. Variables and their levels used in Box-Behnken design

\begin{tabular}{lcccc}
\hline \multirow{2}{*}{ Variable } & & \multicolumn{2}{c}{ Level } \\
\cline { 3 - 5 } & & -1 & 0 & +1 \\
\hline $\mathrm{pH}$ & $X_{1}$ & 4 & 5 & 6 \\
Temperature & $X_{2},{ }^{\circ} \mathrm{C}$ & 25 & 30 & 35 \\
Time & $X_{3}$, days & 4 & 5 & 6 \\
\hline
\end{tabular}

The experimental results were analysed by software Design-Expert 7.0 (State-Ease Inc., Minneapolis, USA) to fit the second-order Eq. (1):

$$
Y=\beta_{0}+\sum_{i=1}^{3} B_{i} \mathrm{X}_{i}+\sum_{i=1}^{3} B_{i i} \mathrm{X}_{i}^{2}+\sum_{i=1}^{3} B_{i j} \mathrm{X}_{i} \mathrm{X}_{j}
$$

where $Y$ stands for peptides content, $X_{1}, X_{2}, X_{3}$ for independent variables, $\beta_{0}, B_{i}, B_{\mathrm{ii}}, B_{\mathrm{ij}}$ for the model intercept and regression coefficients.

\subsection{Measurement of protease activity}

Protease activity was evaluated according to the method described by Li and co-workers (2011). Two grams of frozen germinated seeds were homogenized in $8 \mathrm{ml}$ of $0.02 \mathrm{~mol} \mathrm{l}^{-1}$ citric acid-phosphate buffer (pH 6) containing $2.5 \mathrm{mmol}^{-1}$ ethylene diamine tetraacetic acid and $5 \mathrm{mmol} \mathrm{l}^{-1} 2$-mercaptoethanol in an ice bath. The supernatant (centrifuged for $30 \mathrm{~min}$ at $4{ }^{\circ} \mathrm{C}$ and 10000 r.p.m.) was obtained and used for protease activity assay. The reaction mixture contained $1 \mathrm{ml}$ of $20 \mathrm{~g} \mathrm{l}^{-1}$ casein and $1 \mathrm{ml}$ of enzyme solution. The reaction was carried out for $10 \mathrm{~min}$ at $40{ }^{\circ} \mathrm{C}$ and stopped by incubating in $90{ }^{\circ} \mathrm{C}$ water bath for $5 \mathrm{~min}$. Then, $2 \mathrm{ml}$ of $0.4 \mathrm{~mol} \mathrm{l}^{-1}$ trichloroacetic acid (TCA) was added into the mixture and it was kept at room temperature for $15 \mathrm{~min}$. The supernatant was obtained by centrifugation for 10 min at $4{ }^{\circ} \mathrm{C}$ and 10000 r.p.m. Protease activity was determined according to the increase in absorbance at $275 \mathrm{~nm}$ using a UNIC UV-2802 spectrophotometer (Princeton, USA). One unit of protease activity was defined as the increase of one absorbance unit per min under the determined conditions. The deactivated enzyme, by incubation for $5 \mathrm{~min}$ at $90{ }^{\circ} \mathrm{C}$, was used as control.

\subsection{Determination of peptides content}

Peptides content analysis was performed by the method previously described by WeN and co-workers (2009). Five grams of frozen germinated seeds were homogenized by grinding in $50 \mathrm{ml}$ of $0.2 \mathrm{~mol} \mathrm{l}^{-1}$ phosphate buffer ( $\mathrm{pH} \mathrm{7}$ ). The homogenate was centrifuged for $15 \mathrm{~min}$ at 10000 r.p.m. and the supernatant was deposited by an equal volume of $100 \mathrm{~g} \mathrm{l}^{-1}$ TCA to precipitate macromolecule protein. The supernatant was obtained by centrifugation for 15 min at 10000 r.p.m. Then, $3 \mathrm{ml}$ of supernatant was mixed with $2 \mathrm{ml}$ of biuret reagent. The 
mixture was incubated for $10 \mathrm{~min}$ at $25^{\circ} \mathrm{C}$ and then centrifuged for $15 \mathrm{~min}$ at 10000 r.p.m. The peptides content was determined by supernatant absorbance at $540 \mathrm{~nm}$ using L-glutathione (reduced) as standard, and the results were expressed as $\mathrm{mg} \mathrm{g}^{-1}$ of germinated soybean sample.

\subsection{Statistical analysis}

The experimental data was expressed as mean \pm standard deviation of triplicates. Differences among means were checked by Fisher's F-test at a significance level of $\mathrm{P}<0.05$.

\section{Results and discussion}

\subsection{Effects of $\mathrm{pH}$ on protease activity and peptides content}

Effects of $\mathrm{pH}$ values of culture solution on protease activity and peptides content in germinated soybean are shown in Figure 1. Both protease activity and peptides content increased first and then decreased. When $\mathrm{pH}$ value of culture solution was 5, maximal protease activity (71.69 $\left.\mathrm{U} \mathrm{g}^{-1} \mathrm{FW}\right)$ and highest peptides content $\left(12.42 \mathrm{mg} \mathrm{g}^{-1} \mathrm{FW}\right)$ were obtained.

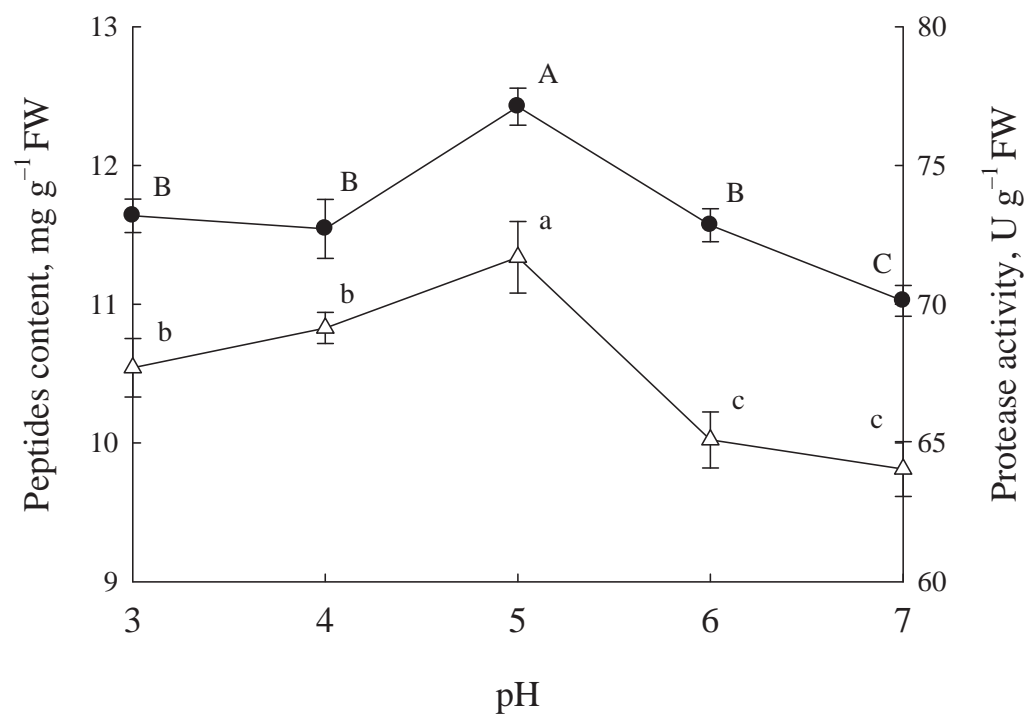

Fig. 1. Effects of $\mathrm{pH}$ on protease activity (open triangle) and peptides content (solid circle). Capital letters and lower case letters reflect the significance of differences in peptides content and protease activity $(\mathrm{P}<0.05)$, respectively

\subsection{Effects of temperature on protease activity and peptides content}

As shown in Figure 2, germination temperature markedly affected protease activity and peptides content. The protease activity increased gradually when temperature increased, but gradually decreased when temperature increased further. The highest protease activity, $65.60 \mathrm{U} \mathrm{g}^{-1} \mathrm{FW}$, was achieved at temperature of $25^{\circ} \mathrm{C}$. The peptides content also increased rapidly with the increase of temperature, but it slowly decreased when temperature was above $30{ }^{\circ} \mathrm{C}$. The maximal peptides content $\left(12.16 \mathrm{mg} \mathrm{g}^{-1} \mathrm{FW}\right)$ was obtained when the temperature was $30^{\circ} \mathrm{C}$. 


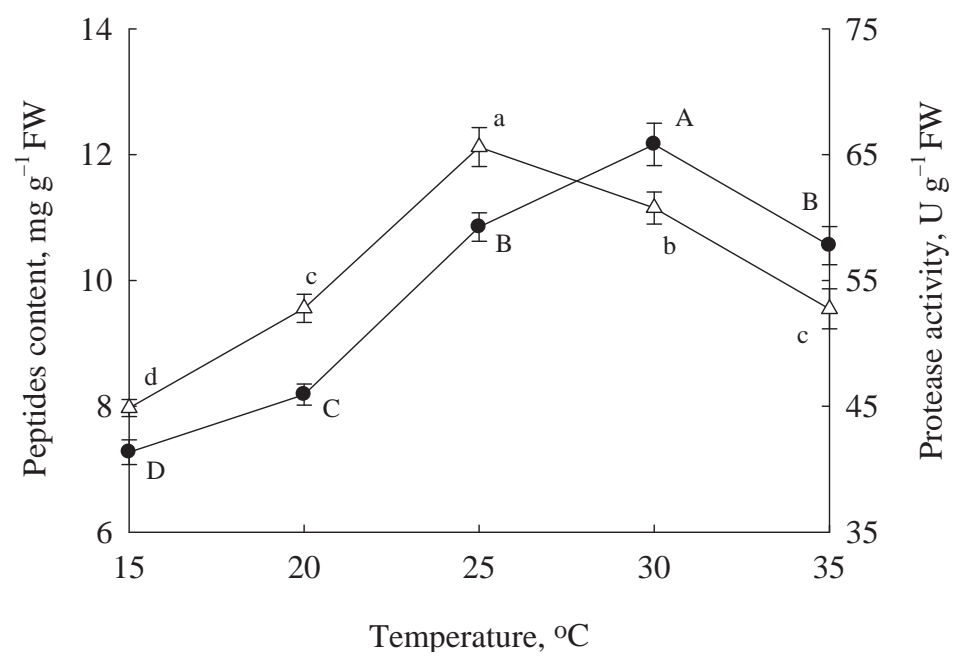

Fig. 2. Effects of temperature on protease activity (open triangle) and peptides content (solid circle). Capital letters and lower case letters reflect the significance of differences in peptides content and protease activity $(\mathrm{P}<0.05)$, respectively

\subsection{Effects of time on protease activity and peptides content}

Effects of germination time on protease activity and peptides content in germinated soybean are shown in Figure 3. The protease activity was enhanced with the extension of germination time, but it reached a constant value $\left(72.06 \mathrm{U} \mathrm{g}^{-1} \mathrm{FW}\right)$ when germination time was between 5 and 6 days. There was a gradual increase in the peptides content with the extension of germination time, but a slight decrease occurred when germination time exceeded 5 days. The maximal peptides content $\left(14.08 \mathrm{mg} \mathrm{g}^{-1} \mathrm{FW}\right)$ was obtained on 5 day of germination.

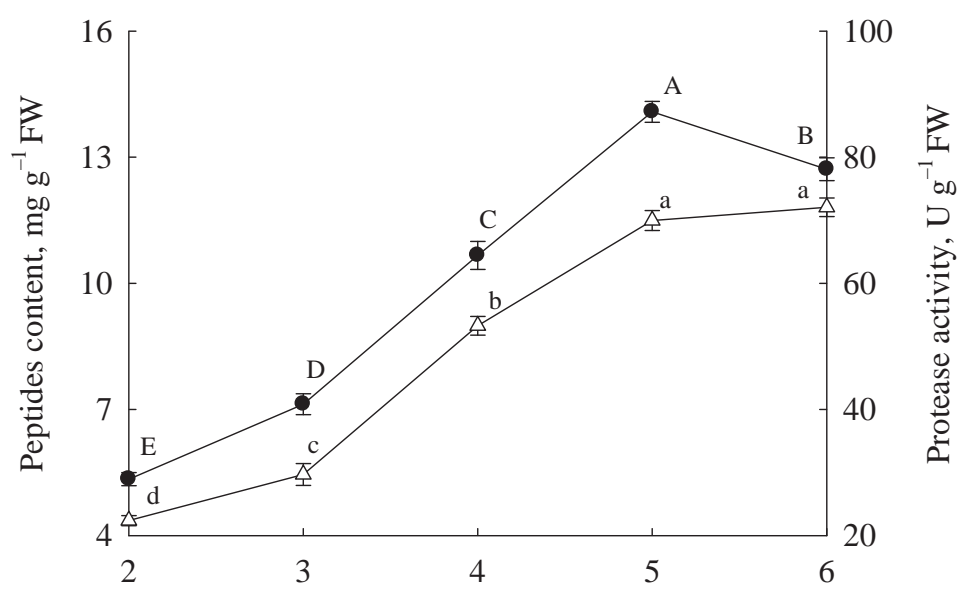

Time, days

Fig. 3. Effects of time on protease activity (open triangle) and peptides content (solid circle). Capital letters and lower case letters reflect the significance of differences in peptides content and protease activity $(\mathrm{P}<0.05)$, respectively 


\subsection{Analysis of Box-Behnken experiment for peptides accumulation}

The germination conditions ( $\mathrm{pH}$, temperature, and time) were further optimised using BoxBehnken design for obtaining the maximum peptides content (Table 2). A fitted polynomial model describing the correlation between peptides content and the three germination conditions was obtained in Eq. (2):

$$
\begin{aligned}
& Y=-80.77+4.09 X_{1}+3.95 X_{2}+10.08 X_{3}-1.28 X_{1}^{2}-0.06 X_{2}^{2} \\
& -1.15 X_{3}^{2}-0.01 X_{1} X_{2}+1.49 X_{1} X_{3}-0.15 X_{2} X_{3}
\end{aligned}
$$

The statistical significance of Eq. (2) was evaluated by F-test, and results are shown in Table 3. The analysis of variance (ANOVA) indicated that the model (F-value of 16.27) was significant $(\mathrm{P}<0.05)$ and the lack of fit $(\mathrm{P}$-value of 0.0871$)$ was not significant $(\mathrm{P}>0.05)$. The coefficient of determination $\left(R^{2}\right)$ was 0.9544 , showing that the response variation of $95.44 \%$ was attributed to independent variables, and the fitted model could be used to optimize germination conditions in this study.

\begin{tabular}{|c|c|c|c|c|}
\hline Run & $X_{1}-\mathrm{pH}$ & $\begin{array}{c}X_{2}-\text { Tempera- } \\
\text { ture }\left({ }^{\circ} \mathrm{C}\right)\end{array}$ & $\begin{array}{c}X_{3}-\text { Time } \\
\text { (days) }\end{array}$ & Peptides content $\left(\mathrm{mg} \mathrm{g}^{-1} \mathrm{FW}\right)$ \\
\hline 1 & 5 & 30 & 5 & $14.06 \pm 0.31$ \\
\hline 2 & 5 & 35 & 6 & $12.49 \pm 0.26$ \\
\hline 3 & 4 & 35 & 5 & $12.25 \pm 0.19$ \\
\hline 4 & 6 & 25 & 5 & $10.18 \pm 0.16$ \\
\hline 5 & 4 & 30 & 6 & $12.31 \pm 0.25$ \\
\hline 6 & 6 & 30 & 4 & $7.42 \pm 0.11$ \\
\hline 7 & 6 & 30 & 6 & $12.27 \pm 0.23$ \\
\hline 8 & 5 & 30 & 5 & $14.11 \pm 0.27$ \\
\hline 9 & 5 & 25 & 6 & $14.09 \pm 0.33$ \\
\hline 10 & 5 & 30 & 5 & $13.31 \pm 0.30$ \\
\hline 11 & 5 & 30 & 5 & $14.12 \pm 0.28$ \\
\hline 12 & 5 & 35 & 4 & $10.08 \pm 0.22$ \\
\hline 13 & 4 & 30 & 4 & $13.45 \pm 0.26$ \\
\hline 14 & 6 & 35 & 5 & $9.79 \pm 0.18$ \\
\hline 15 & 4 & 25 & 5 & $12.54 \pm 0.28$ \\
\hline 16 & 5 & 25 & 4 & $8.61 \pm 0.13$ \\
\hline 17 & 5 & 30 & 5 & $13.36 \pm 0.15$ \\
\hline
\end{tabular}

Table 2. Experimental design and observed peptides yield

\subsection{Optimisation of germination conditions and verification of model}

According to the Design Expert software test results and its application value to the practical production, the optimal germination conditions to obtain the highest peptides content in soybean were determined as follows: $\mathrm{pH} 4.8$, temperature $29{ }^{\circ} \mathrm{C}$, and time 5 days. The peptides content was $14.46 \pm 0.26 \mathrm{mg} \mathrm{g}^{-1} \mathrm{FW}$ and this value was not significantly $(\mathrm{P}>0.05)$ different from predicted value $\left(14.31 \mathrm{mg} \mathrm{g}^{-1} \mathrm{FW}\right)$. These results proved that the model designed in this study was valid. 
Table 3. ANOVA of fitted regression model

\begin{tabular}{lccccc}
\hline Source & Sum of squares & Degree of freedom & Mean squares & $F$-value & P-value \\
\hline Model & 65.21 & 9 & 7.25 & 16.27 & 0.0007 \\
$X_{1}-\mathrm{pH}$ & 14.82 & 1 & 14.82 & 33.29 & 0.0007 \\
$X_{2}-$ Temperature & 0.08 & 1 & 0.08 & 0.18 & 0.6807 \\
$X_{3}-$ Time & 16.82 & 1 & 16.82 & 37.78 & 0.0005 \\
$X_{1}^{2}$ & 6.88 & 1 & 6.88 & 15.46 & 0.0057 \\
$X_{2}^{2}$ & 7.38 & 1 & 7.38 & 16.57 & 0.0047 \\
$X_{3}^{2}$ & 5.58 & 1 & 5.58 & 12.53 & 0.0095 \\
$X_{1} X_{2}$ & 0.01 & 1 & 0.01 & 0.01 & 0.9424 \\
$X_{1} X_{3}$ & 8.97 & 1 & 8.97 & 20.15 & 0.0028 \\
$X_{2} X_{3}$ & 2.36 & 1 & 2.36 & 5.29 & 0.0550 \\
Lack of fit & 2.42 & 3 & 0.81 & 4.61 & 0.0871 \\
Pure error & 0.70 & 4 & 0.17 & & \\
Corrected total & 68.33 & 16 & $R^{2}=0.9544$ & & \\
\hline
\end{tabular}

Protease plays a critical role in the metabolism of protein during germination of legumes. Factors like germination conditions can activate or inhibit protease and effectively regulate protein metabolism (Jones, 2005). The storage proteins in plant seeds are cleaved to form a variety of peptides by specific endoproteinases (CALLIS, 1995). Therefore, high levels of peptides can accumulate in plant tissues during germination. Although some peptides have been prepared using purified proteases or expensive chemical methods (KAN \& DANISHEFSKY, 2009), using endogenous proteases to generate bioactive peptides during germination is a more economical and efficient preparation method, thus further research on peptides accumulation in germinated seeds is necessary.

Appropriate $\mathrm{pH}$ value of culture solution can activate proteases and promotes the synthesis of intracellular peptides by hydrolyzing the storage proteins (Wen et al., 2009). The protease activity in germinated soybean first increased and then decreased with increasing $\mathrm{pH}$ (Fig. 1). The optimum $\mathrm{pH}$ for soybean germination was 5, with a protease activity of 71.69 $\mathrm{U} \mathrm{g}^{-1} \mathrm{FW}$. The peptides content also showed the same trend, indicating the importance of protease activity for peptides formation. The optimal values of other proteases from cereals or legumes had been reported as $\mathrm{pH} 5.5$ for wheat germ (YANG et al., 2011), pH 5 for sorghum malt (OGBonna et al., 2003), and pH 5.5 for horse gram (RAJEswARI et al., 2009), which was very similar to result in this study.

An optimal temperature is very important for the reaction of an enzyme. At lower temperature the enzyme is not activated, while high temperature may destroy the spatial structure of the enzyme resulting the loss of catalytic ability (Zou et al., 2015). The present results showed that the protease activity increased with the temperature from 15 to $25{ }^{\circ} \mathrm{C}$, then decreased from 25 to $35^{\circ} \mathrm{C}$ (Fig. 2). The highest protease activity in germinated soybean was $65.60 \mathrm{U} \mathrm{g}^{-1} \mathrm{FW}$ when temperature was $25^{\circ} \mathrm{C}$, which agreed with results reported by HÜBNER and ARENDT (2010). The peptides content showed a similar trend, but the maximum was obtained when temperature was $30^{\circ} \mathrm{C}$. The peptides yield in germinated seeds is related not only to endogenous proteases, but also to endogenous peptidases that are responsible for the breakdown of peptides into amino acids (CALLIS, 1995). Therefore, the optimal temperature 
for protease activity might be inconsistent with that for peptides accumulation in the same plant.

The germination time is one of the important factors that influence protease activity and peptides accumulation (HÜBNER \& ARENDT, 2010). As shown in Figure 3, protease activity and peptides content rapidly increased over the first 5 days of germination. The protease activity continued to remain at a high level from 5 to 6 days of germination, but the peptides content significantly decreased after 5 days of germination. This phenomenon happened because more peptides would be degraded to amino acids or converted into other nutritional components during the later period of germination (JonEs, 2005). Hence, the extension of germination time would not further enhance the peptides yield in soybean. This finding makes the whole process of sprouting economically more feasible and efficient in the potential application in industrialised production of peptides-enriched legumes.

Statistical methods for conditions optimisation have been successfully utilized for production of many bioactive compounds during germination (Li et al., 2010; PERALESSÁncheZ et al., 2014; CAO et al., 2015). In this study, statistical optimisation of germination conditions for peptides accumulation in soybean was carried out by the single-factor experiment and RSM. The maximal peptides content $\left(14.46 \mathrm{mg} \mathrm{g}^{-1} \mathrm{FW}\right)$ obtained provided a $25 \%$ increase compared with the initial yield ( $\left.11.54 \mathrm{mg} \mathrm{g}^{-1} \mathrm{FW}\right)$ using un-optimised germination conditions ( $\mathrm{pH} 4$, temperature $25{ }^{\circ} \mathrm{C}$, and time 4 days). In conclusion, the combination of single-factor experiment and RSM proved to be very effective in improving peptides accumulation in soybean.

\section{Conclusions}

The $\mathrm{pH}$, temperature, and time influenced protease activity and increased peptides yield during germination of soybean. The best combinations of germination conditions for peptides accumulation were $\mathrm{pH} 5$, temperature $29^{\circ} \mathrm{C}$, and time 5 days. Under optimised conditions, the highest peptides content, $14.46 \mathrm{mg} \mathrm{g}^{-1} \mathrm{FW}$ was obtained. The present study indicates that the germinated soybean can be a valuable component of peptides-enriched foods.

\section{References}

Agarwal, D.K., Billore, S.D., Sharma, A.N., Dupare, B.U. \& Srivastava, S.K. (2013): Soybean: Introduction, improvement, and utilization in India - problems and prospects. Agr. Res., 2, 293-300.

BAI, Q., FAN, G., Gu, Z., CAO, X. \& Gu, F. (2008): Effects of culture conditions on $\gamma$-aminobutyric acid accumulation during germination of foxtail millet (Setaria italica L.). Eur. Food Res. Technol., 228, 169-175.

Callis, J. (1995): Regulation of protein degradation. Plant Cell, 7, 845-857.

CAO, Y., JiA, F., HAN, Y., LIU, Y. \& ZHANG, Q. (2015): Study on the optimal moisture adding rate of brown rice during germination by using segmented moisture conditioning method. J. Food Sci. Tech., 52, 6599-6606.

Dia, V.P., Gomez, T., Vernaza, G., Berhow, M., Chang, Y.K. \& de Mejia, E.G. (2012): Bowman-Birk and Kunitz protease inhibitors among antinutrients and bioactives modified by germination and hydrolysis in Brazilian soybean cultivar BRS 133. J. Agr. Food Chem., 60, 7886-7894. 
HüBNER, F. \& ARENDT, E.K. (2010): Studies on the influence of germination conditions on protein breakdown in buckwheat and oats. J. I. Brewing, 116, 3-13.

Jones, B.L. (2005): Endoproteases of barley and malt. J. Cereal Sci., 42, 139-156.

KAN, C. \& DANISHEFSKY, S.J. (2009): Recent departures in the synthesis of peptides and glycopeptides. Tetrahedron, $65,9047-9065$.

Kumari, S., Krishnan, V. \& SAChDEv, A. (2015): Impact of soaking and germination durations on antioxidants and anti-nutrients of black and yellow soybean (Glycine max. L) varieties. J. Plant Biochem. Biot., 24, 355-358.

LI, C., CAO, X., Gu, Z. \& WEN, H. (2011): A preliminary study of the protease activities in germinating brown rice (Oryza sativa L.). J. Sci. Food Agr., 91, 915-920.

LI, Y., BAI, Q., JIN, X., WEN, H. \& GU, Z. (2010): Effects of cultivar and culture conditions on $\gamma$-aminobutyric acid accumulation in germinated fava beans (Vicia faba L.). J. Sci. Food Agr., 90, 52-57.

Liu, X., Jin, J., Wang, G. \& Herbert, S.J. (2008): Soybean yield physiology and development of high-yielding practices in Northeast China. Field Crop Res., 105, 157-171.

Mune Mune, M.A., Minka, S.R. \& Mbome, I.L. (2008): Response surface methodology for optimisation of protein concentrate preparation from cowpea (Vigna unguiculata (L.) Walp). Food Chem., 110, 735-741.

Mune Mune, M., Saxena, D. \& Minka, S.R. (2014): Antioxidant activity of cowpea protein isolate hydrolyzed by pepsin. Acta Alimentaria, 43, 614-622.

Ogbonna, А., Ові, S., Окоцо, B. \& Оріво, F. (2003): Purification and some properties of a protease from sorghum malt variety KSV8-11. J. I. Brewing, 109, 179-186.

Peñas, E., Gómez, R., Frías, J. \& Vidal-Valverde, C. (2010): Effects of combined treatments of high pressure, temperature and antimicrobial products on germination of mung bean seeds and microbial quality of sprouts. Food Control, 21, 82-88.

Perales-Sánchez, J.X.K., Reyes-Moreno, C., Gómez-Favela, M.A., Milán-Carrillo, J., Cuevas-Rodríguez, E.O., Valdez-Ortiz, A. \& GutiÉrRez-Dorado, R. (2014): Increasing the antioxidant activity, total phenolic and flavonoid contents by optimizing the germination conditions of amaranth seeds. Plant Food Hum. Nutr., 69, 196-202.

Przybylski, R., Firdaous, L., Chataigne, G., Dhulster, P. \& Nedjar, N. (2016): Production of an antimicrobial peptide derived from slaughterhouse by-product and its potential application on meat as preservative. Food Chem., 211, 306-313.

Rajeswari, J., Vadde, R., Sridhar, R. \& Ramakrishna, R. (2009): Purification and characterization of cysteine protease from germinating cotyledons of horse gram. BMC Biochem., 10, 1-10.

Shao, S., Duncan, A.M., Yang, R., Marcone, M.F., Rajcan, I. \& Tsao, R. (2009): Tracking isoflavones: From soybean to soy flour, soy protein isolates to functional soy bread. J. Funct. Foods, 1, 119-127.

Wen, H.B., CAO, X.H., Gu, Z.X., TANG, J.T. \& HAN, Y.B. (2009): Effects of components in the culture solution on peptides accumulation during germination of brown rice. Eur. Food Res. Technol., 228, 959-967.

YANG, R., Song, J., Gu, Z. \& LI, C. (2011): Partial purification and characterisation of cysteine protease in wheat germ. J. Sci. Food Agr., 91, 2437-2442.

Zou, Y., Hu, W., Jiang, A. \& Tian, M. (2015): Partial purification and characterization of a novel histidine decarboxylase from Enterobacter aerogenes DL-1. Prep. Biochem. Biotech., 45, 605-615. 